\title{
Study on the Opening of Local Culture English Course
}

\author{
Min Zhang \\ School of Foreign Languages \\ Nanyang Institute of Technology \\ Nanyang, China
}

\begin{abstract}
As an essential part of the colorful Chinese culture, local culture has always been neglected in colleges' teaching syllabus. In view of the author's practical working experience and the former research findings, the author suggests opening some local culture English courses among Chinese college students. This paper mainly investigates the feasibility and necessity of opening such local culture English courses in Chinese local colleges.
\end{abstract}

Keywords-local culture; Chinese local colleges; English courses

\section{INTRODUCTION}

Culture is a nation's root and soul. Culture is also the base of a nation to keep exuberant vitality. However, culture education is often been neglected in China's education system. Although the cultivation of cross-culture thinking mode is often been mentioned in some English courses, the so-called "cross-culture" mainly focuses on the study of western culture and neglects its own native culture. Just as a researcher says, "Our cross-culture theories and practices lack a sense of equal communication. ... A student is often asked to suit the foreign culture, but has little chance to input the excellent Chinese culture." With the development of economic globalization and the increase of Chinese national power, more and more foreigners begin to be interested in Chinese culture, and put China as one important destination in their usual travel plan.

In addition to this, as an important soft power, culture is being stressed by all countries. As an indispensable communication tool, culture is playing a more and more important role in the national relations. Most countries, especially the western powerful countries, attach great importance to the usage of culture to promote their world value and increase their influential power. To strengthen the culture communication and cooperation is a responsibility and also a mission. As an essential part of world culture, local culture is often been neglected. An an important output base of local talents, local colleges must strengthen the local culture education. After understanding fully his native local culture, a student would be possible to like Chinese general culture and then to effectively spread it.

In view of the author's above working experience and the former research findings, the author suggests to open a local culture English course. On the basis of a questionnaire survey, this paper tries to discuss its feasibility and necessity.

\section{LITERATURE REVIEW}

Recently, with the promotion of developing a "powerful cultural country" and the increase of its culture soft power, more and more researches begin to transform to the Chinese culture. However, the majority of them still mainly focus on the discussion of the whole general culture, or the courses building of Chinese culture. Yuan Yuan, for example, discovers that there are very few Chinese culture courses for the English-major students after thoroughly analyzing the present courses that the English major students have. She also finds that as high as $87.82 \%$ of her students admits the necessity of the series of Chinese culture courses. After investigating ten colleges in Zhejiang province, Zhenhua Zhu concludes that " There are very few kind of Chinese culture courses among English-major students, and there exists a widespread phenomenon of cultural aphasia." Lemin Shen also finds that the students' Chinese culture translation ability is very weak after investigate six colleges in Ningbo city, Zhejiang province, China. Most of these researches take the English-major students as their studying subject, and put their emphasis on the importance of Chinese culture courses among English major students. But in reality, English major students are only the minority group in a college. It is very hard to fulfill the mission of spreading Chinese culture only depending on them. The true backbone force should be the majority of non-English major students. But very few researches mention the Chinese local culture courses towards them.

In view of the above analysis, this paper attempts to make up the blank by taking the whole college students, including both English-major and non-English major students, as the research subject, put the increase of their local cultural quality as the research content, and focuses on the discussion of the feasibility and necessity of the establishment of a series of Chinese local culture courses. Since local culture can be always touched by the students, to reinforce the permeation of Chinese local culture can help to increase the students' national pride and sense, and their culture consciousness. 


\section{QUESTIONNAIRE DESIGN}

He who makes no investigation and study has no right to speak. Is it necessary to start a Chinese local culture English course in Chinese local colleges? Do the students like it? With these questions, a questionnaire survey is conducted in Henan province, which is the author's working place, in the first half year of 2016 .

\section{A. Subject}

The investigation takes students from Henan University of Finance and Economics, Nanyang Institute of Technology, Henan Polytechnic University, Pingdingshan Normal School as the subject. These four colleges belong to the four different places in Henan province, China, which can stand for the whole local colleges in Henan province.

\section{B. Investigation Method}

With the help of a free questionnaire platform in the website of www.sojump.com, the investigation requires the students to hand in the questionnaire through their computer or smartphone. By the way of voluntary and anonymous method, the investigation completely reduce the students' burden of being punished if they said some truth. This kind of investigation method has at least the following four advantages:

- Convenient;

- Economy for saving the expense of photocopying;

- More precise by making the computer rather than the human beings to count the data, which can reduce the chance of making mistakes;

- More accurate because the anonymous and voluntary method can fully free the students' worries.

\section{Data Gathering}

This investigation lasts for a week, which ranges from the April 5th to April 12th. 377 questionnaires are gathered and all are valid. The subjects include both English major and non-English major students and students of sciences occupy the majority. Most are the 2015 freshman, with the age of 18 to 25 .

\section{DISCUSSION}

\section{A. Necessity}

1) To learn about local culture is very important: As an essential part of China's excellent culture, various local cultures consist of the whole national culture. As a reflection of a special customs, habits, popularity, etc. local culture is the base for a place to exist in the world, and is a sign to differentiate with other places. One wants to know Chinese culture, he must first know the local culture that he is living in. After one fully understand about a his local culture, he would be interested in the culture itself, which will further inspire or drive him or her to learn more about the nation's culture. Hence, to know China must first know the local culture.

2) Students in the local colleges know little about their local culture: As the hope and new generation of China, students is taking the important duty of spreading local culture. To teach them the local culture is helpful to spread the local culture, which in further would help the effect of communication with other countries. However, investigation shows that students in the local colleges know very little about their local culture. Comparatively speaking, students know a little more about the ancient capitals, local customs, food than the other cultures such as the history, religion, science and technology, education, ideology, philosophy, medicine, literature, sages, etc. The discovery proves that it is quite necessary to open some local culture English course $\mathrm{s}$ in the local colleges.

3) Students' local culture English is very poor: In order to investigate the students' English level of local culture English expression, 20 common local culture Chinese words or expressions are selected for the students to translate them into English with the help of internet or dictionary. The scoring standard is also not very strict. If the students can express the basic meaning of the culture, they will get the full marks. Take LUO YANG SHUI XI as an example, "LuoYang water banquet, water seats, water party, LuoYang Shuixi" are all correct translation. Another example of "JIA GU WEN"(a special written words inscribed in the back of a turtle) oracle, bone text, inscription on bones, are all good translation. And XIAO LONG BAO ZI (a traditional Chinese food) is translated into "big dumpling, small hamburger, small steamed bun, small buns in the cage", which is also good. SHI JING ( a Chinese poem) transated as "poem songs, classic of poetry, the book of songs, the book of odes" is also acceptable. With this tolerant standard, as is shown in "Table I", the number of students who got half right $(50 \%)$ is only 30 , which accounts for $7.96 \%$. In contrast, 266 students got zero or wrote nothing, which accounts for $70.56 \%$. This proves the poverty of students' local culture English expressing ability. With the help of internet and dictionary, the students can not fully express themselves about their local culture. If there were no internet or dictionary, the result would be much worse. The result shows the urgency of promoting local culture education in the local colleges.

TABLE I. RESUlt OF THE TEST ON THE LOCAL CUlture ENGLISH EXPRESSION

\begin{tabular}{|l|l|l|l|}
\hline $\begin{array}{c}\text { Numbers of } \\
\text { words that they } \\
\text { get scores }\end{array}$ & \multicolumn{1}{|c|}{$\mathbf{0}$} & $\begin{array}{c}\text { Less } \\
\text { than10 }\end{array}$ & $\begin{array}{c}\text { More } \\
\text { than 10 }\end{array}$ \\
\hline Persons' number & 266 & 81 & 30 \\
\hline percentage & $70.56 \%$ & $21.49 \%$ & $7.96 \%$ \\
\hline
\end{tabular}

In addition to this, the questionnaire also points out another problems that exist in the students. That is to say, to the majority of local culture, the students only know a side aspect but not fully understand them. For example, SHUI HUI in MAJIE SHU HUI is often translated into an activity 
concerned with BOOK, such as "book meeting, book gathering, book festival, book reading, book party, book gallery, book club, book share"etc. But in fact, the SHUI in MAJIE SHU HUI has nothing to do with BOOK. It is a general terms of the artists' performance with or without such musical instrument as Suona, flute, violin, Guzheng, Pipa, and other traditional Chinese musical instrument. Therefore MAJIE SHU HUI is neither a "book club or party" nor a "book festival", but a splendid gala of folk artists. And LUO YANG SHUI XI has nothing to do with the English word WATER. It has two connotations. One means that all hot dishes are accompanied with soup, in Chinese TANG TANG SHUI SHUI. The other meaning is that after one hot dish is finished, there would be another dish afforded, which is just like water continuously flowing. In view of this, all translation with WATER is not a proper translation. But actually, among the total 377 students, only 63 give answers to the translation of LUOYANG SHUI XI, among which 58 translate LUOYANG SHUI XI with WATER, another 5 students use directly Chinese Pinyin without further explanation. The test proves the poverty of local students' local culture translation and also the shortage of their understanding about the connotation of local culture.

4) Most foreigners are eager to know more about the local Chinese culture: One of the author's daily routine is to receive various foreigners. The reason for most foreigners to come to China is that they are interested in Chinese old, abundant and mysterious culture. When talking with them, they all desire me to introduce some specials to them. As to the worldwide famous stuff, such as the Great Wall, the Forbidden City, Confucius, Chairman Mao, Buddhism, Peking Toast Duck, etc. they all have been known them a lot, and some even know much more than our Chinese native people. What they desire most is those that are very interesting but they can not get from the common public media, such as internet or books, such as the local folklore, anecdote, etc. instead of a general introduction. Take Nanyang city, Henan province as an example. When a foreigner arrives at Nanyang, in comparison with the routine western-style food or buffet, they tend to favor some Nanyang's characteristic and classic food, for example, Fang Cheng Hui Mian ( Fang Cheng Stewed Noodles), Bowang Guo Kui ( a crusty pancake made in Bowang village, Fangcheng district, Nanyang City. It is large as a plate, and think as a western bread, but it is crisp and fragrant when chewing.) etc. In addition to the simple introduction of its making process, dressings, and eating methods, some stories, funny things, anecdotes about them are most welcomed by many foreigners. To some extent, they are not only eating Chinese food, they are eating Chinese culture. The beautiful local culture can greatly increase their love to the city, and even to China. The more they come to China, the more they want to come again. All of this good feeling comes from the local culture. Therefore, it has great significance to have more people fully and deeply understand the local culture.

\section{B. Feability}

The discussion above proves the necessity of opening local culture English courses in the Chinese local colleges. But is it feasible to open such courses? The questionnaire also proves that.

1) Students are eager to know more about their local culture: As shown in "Fig. 1" over $80 \%$ $(68.44 \%+15.38 \%+1.59 \%)$ students admit that they don't know or know only a little about Henan's local culture. When asking about the causes, most students think it is due to the missing of local culture education in school, for example, " there is no such courses", "there is no such content in the English textbooks", or "there's no such test", etc. as is shown in "Table II".

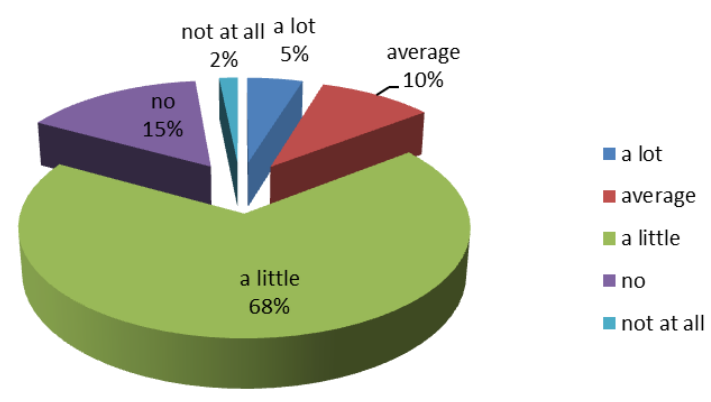

Fig. 1. Answers to the question of "how much do you know about Henan's local culture?"

TABLE II. What ARE THE MAIN REASONS That You Don'T KNOW Much about Henan's Local Culture? [Multipl CHOICE]

\begin{tabular}{|l|l|l|}
\hline \multicolumn{1}{|c|}{ options } & \multicolumn{1}{|c|}{$\begin{array}{c}\text { Sub- } \\
\text { total }\end{array}$} & percentage \\
\hline $\begin{array}{l}\text { A. There's no local } \\
\text { culture test }\end{array}$ & 99 & $31.03 \%$ \\
\hline $\begin{array}{l}\text { B Teachers do not } \\
\text { teach it. }\end{array}$ & 67 & $21 \%$ \\
\hline $\begin{array}{l}\text { C. There's no such } \\
\text { courses. }\end{array}$ & 172 & $53.92 \%$ \\
\hline $\begin{array}{l}\text { D. There is no such } \\
\text { content in the English } \\
\text { textbooks }\end{array}$ & 108 & $33.86 \%$ \\
\hline $\begin{array}{l}\text { E. I have no interest in } \\
\text { it. }\end{array}$ & 62 & $19.44 \%$ \\
\hline $\begin{array}{l}\text { F. I have no time to } \\
\text { learn it. }\end{array}$ & 85 & \\
\hline $\begin{array}{l}\text { G. I don't know. } \\
\text { I. Other reasons }\end{array}$ & 26 & $26.65 \%$ \\
\hline $\begin{array}{l}\text { H. I know little about it } \\
\text { because I am not from } \\
\text { Henan. }\end{array}$ & 83 & \\
\hline
\end{tabular}


In spite of the fact that they know little about the local culture and it is not compulsive in the college, over $90 \%$ $(39.62 \%+52.79 \%)$ students believe it is quite necessary or strongly necessary for them to learn more about Henan's local culture, as is shown in "Fig. 2".

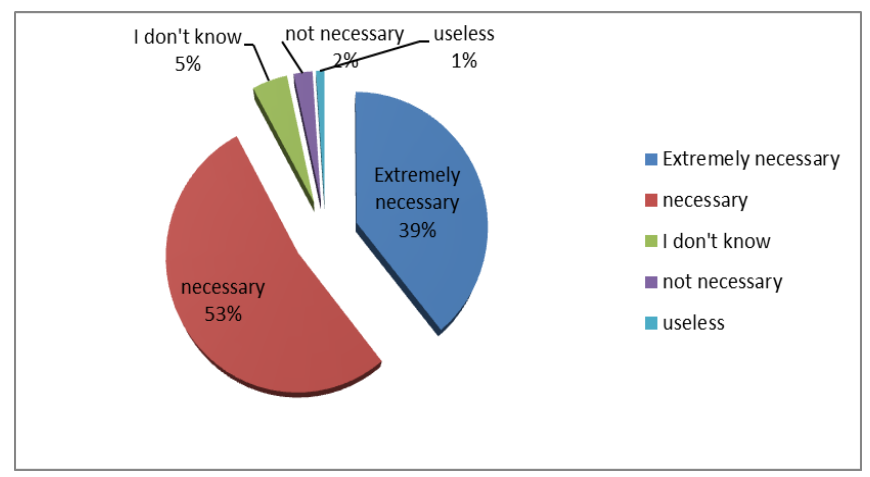

Fig. 2. Answers to the question of "Is it necessary for you to learn Henan's local culture?"

In addition to this, as is shown in "Table III", 66.05\% students hopes their English teachers can supplement some English expressions about Henan's local culture, and 51.19\% students hope their English teachers can provide them some English booklists or website address for them to learn it.

TABLE III. WHAT DO YOU MOST HOPE YOUR ENGLISH TEACHERS TO DO IN THE CLASS AS TO THE SPREADING OF HENAN'S GOOD LOCAL Culture? [Multiple CHOICE]

\begin{tabular}{|l|l|l|}
\hline \multicolumn{1}{|c|}{ Options } & $\begin{array}{l}\text { Sub- } \\
\text { total }\end{array}$ & \multicolumn{1}{|c|}{ percentage } \\
\hline $\begin{array}{l}\text { A. I hope our Englsih teacher } \\
\text { supplementmore English expressions } \\
\text { about Henan's local culture. }\end{array}$ & 249 & \\
\hline $\begin{array}{l}\text { B. I hope our English teacher } \\
\text { provide us some English booklists or } \\
\text { website address for us to learn it after } \\
\text { class. }\end{array}$ & 193 & \\
\hline $\begin{array}{l}\text { C. It's none of the English teacher's } \\
\text { business to spread Henan's local } \\
\text { culture. }\end{array}$ & 55 & \\
\hline & & \\
\hline D. others & 45 & \\
\hline
\end{tabular}

As to the idea of starting a Henan local culture English course, nearly $60 \%(29.97 \%+29.44 \%)$ clearly indicate that they would choose this course if there were local culture English courses, as is shown in "Table IV".
TABLE IV IF THERE WERE A SELECTIVE COURSE ABOUT HENAN Local Culture ENGLISH Courses, Would You LiKe to ChOOSE IT?

\begin{tabular}{|l|l|l|}
\hline \multicolumn{1}{|c|}{ Option } & $\begin{array}{l}\text { Sub- } \\
\text { total }\end{array}$ & percentage \\
\hline $\begin{array}{l}\text { A. I would choose it } \\
\text { because it sounds } \\
\text { interesting. }\end{array}$ & 113 & $29.97 \%$ \\
\hline $\begin{array}{l}\text { B. I would choose it } \\
\text { because I would liketo } \\
\text { know more about Henan } \\
\text { local culture. }\end{array}$ & 111 \\
\hline $\begin{array}{l}\text { C. I would not choose it } \\
\text { because My English is } \\
\text { poor. }\end{array}$ & 127 & $33.69 \%$ \\
\hline $\begin{array}{l}\text { D. If there were many } \\
\text { other people choose it, I } \\
\text { would also choose it. }\end{array}$ & 26 & $6.9 \%$ \\
\hline
\end{tabular}

2) To open the local culture English courses fit for the nation's macro strategy, the local college's syllabus and the requirements of comprehensive foreign language talents: As an important soft power, culture has been given great importance in China. Both the nation and the local states have proposed a culture powerful nation policy. Local colleges attach great importance to the cultivation of their graduate's ability to serve the local economy, and local culture is one of their goals. And a comprehensive foreign language talent also need to know fully about their local culture. In these aspects, to open the local culture English courses fit for the nation's macro strategy, the local college's syllabus and the requirements of comprehensive foreign language talents.

3) Most foreign language teachers in the local colleges come from their native hometown: Most teachers in the foreign language department of local colleges come from the local places. They know a lot about their hometown and they are glad to share the beautiful culture to their students.

\section{CONCLUSION}

A side water and soil raises one party people. The difference of the terrain, climate, history, humanity, economic development makes the various, colorful, special local culture which make up of the beautiful world. Local culture is not only an indispensable part of the world culture, but also a precious treasure of all nations. As a country's future builder and successor, College students shoulder the responsibility of spreading local culture. To open the local culture English course can not only raise their taste and interest, but also keep the vitality of local culture, which in the end helps to promote the inherit, spreading and communication of local culture.

Through the analysis of the above investigation, because there were no courses about local culture, most people feel that their local culture knowledge storage is far from enough, 
and they hope their English teachers could supplement those knowledge or provide them some booklists for them to study. In addition, if there were optional courses about local culture, most people would like to choose it although they are not forced to learn it or test it. Therefore, it is strongly necessary and feasible to start the local culture English courses in the local colleges, which can not only improve the students' local culture expressing ability, but also increase their local culture quality, their national pride, and their ability to spread local culture, which can further help to promote the realization of China's powerful cultural country strategy. However, to open a new course is not an easy job, especially to the local culture. There are not ready-made teaching materials, and united translation theories to the local culture translation. And also the teachers' translation level is not the same. There are still a lot of challenges and difficulties in front. In spite of this, we should not give it up but head on. It is suggested that a start uncompulsory or selected local culture English courses is opened at first. In this way, both the teachers and students would not feel it is a heavy burden to learn local culture. Gradually, it could become a compulsory and general courses in the local colleges.

\section{REFERENCES}

[1] Gardner D, Miller L. Establishing self-access: From theory to practice [J]. System, 1999, 28.

[2] Guo Xue-wen, An Analysis on the Construction of Top-quality Course of College English: Problems and Countermeasures, Journal of Sichuan Normal University (Social Science Edition), 2013, 40 (3), pp. 77-82.

[3] Ji Shou-rong. On Enrichment Courses in College English Teaching in Provincial Universities. Journal of Heilongiiang College of Education 2011, 30 (7), pp. 170-171.

[4] Xing Ruofeng. The Practice and Reflection of the construction of college English elaborate courses---Take Inner Mongolia Finance and Economics College for Example. Jounal of Inner Mongolia Finance and Economics College, 2011, 09 (1), pp. 68-70. 